\title{
The impact of participation in the SAGE study on parent behavior
}

\author{
R Chooniedass ${ }^{1,2^{*}}$, AL Kozyrskyj ${ }^{2,3}, A B$ Becker ${ }^{1,2}$ \\ From Canadian Society of Allergy and Clinical Immunology Annual Scientific Meeting 2009 \\ Halifax, Canada. 22-25 October 2009
}

\section{Objective}

To assess whether participation in the SAGE study, a non-interventional child health cohort study, impacted on behavior change of study participants.

\section{Hypothesis}

Among children sensitized to house dust mites (HDM), families will modify their home environment if the child has asthma.

\section{Method}

This was an analysis of the SAGE nested case-control, comprised of children with asthma (40\%), no asthma and no allergy (40\%), and rhinitis no asthma (20\%). 486 children were seen at 8-10 years and again at 12-13 years. All children were assessed by a pediatric allergist and had skin testing to common aeroallergens. At 8-10 years, the families of children with a positive sensitization to HDM received an information brochure on environmental control for HDM. Parent modification of their home environment was defined as encasement of the child's mattress or pillow and/or removal of carpet for the child's bedroom.

\section{Results}

113 of the 486 children were sensitized to HDM (D. pteronyssinus or D.farinae). Of the 113 families, 49 undertook a home environment change. $30 / 49$ (61\%) of parents had children with asthma and 19/49 (39\%) did not. Interestingly, the percent of parents who modified their environment did not significantly differ between those with asthmatic children (44\%) and those with healthy children (42\%).

\section{Conclusion}

Almost two-thirds of the families in the SAGE study made changes to their home environment because of

${ }^{1}$ Manitoba Institute of Child Health, Canada
HDM sensitization in their asthmatic child. However, these families were no more likely to change their environment than families with a child without asthma. We need to better understand the factors involved with parents' willingness to modify their home environment for a child with asthma.

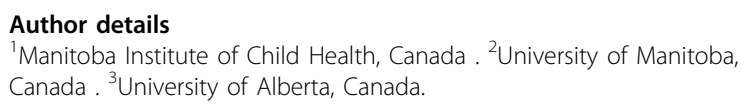

Published: 12 May 2010

doi:10.1186/1710-1492-6-S1-P5

Cite this article as: Chooniedass et al:: The impact of participation in the SAGE study on parent behavior. Allergy, Asthma \& Clinical Immunology 2010 6(Suppl 1):P5.

\section{Submit your next manuscript to BioMed Central and take full advantage of: \\ - Convenient online submission \\ - Thorough peer review \\ - No space constraints or color figure charges \\ - Immediate publication on acceptance \\ - Inclusion in PubMed, CAS, Scopus and Google Scholar \\ - Research which is freely available for redistribution \\ Submit your manuscript at www.biomedcentral.com/submit}

